v. $12, n .2$

Vitória-ES, Mar.-Apr. 2015

p. $66-86 \quad$ ISSN 1808-2386 DOI: http://dx.doi.org/10.15728/bbr.2015.12.2.4

\title{
Analysis of Attributes and Dimensions of the Built Environment Quality from the Perspective of Employees from Furniture Companies
}

\author{
Gabriel Sperandio Milan ${ }^{\dagger}$ \\ Caxias do Sul University \\ Marcelo Benetti Correa da Silva ${ }^{\Omega}$ \\ Caxias do Sul University \\ Suélen Bebber ${ }^{*}$ \\ Caxias do Sul University
}

\begin{abstract}
The analysis of the attributes and dimensions of the built environment quality (workspace) of companies is relevant, because it is associated to the expectations and perceptions of their employees and related to its satisfaction, productivity and business performance. Thus a survey research was implemented in five furniture companies, located inside the Rio Grande do Sul state, focusing on identifying the dimensions of the quality of the built environments analyzed, and their respective attributes, using as a basis previous studies of the area. Unlike the literature, the study identified seven dimensions of the built environment quality (configuration, appearance, functionality, specific activities, personal relationships, company location and comfort), composed of thirty-one attributes. It was also observed the overall satisfaction of employees of these companies in relation to the work environment, which resulted in a rate of $66.00 \%$.
\end{abstract}

Keywords: Quality. Quality dimensions. Built environment. Post-occupancy evaluation. Furniture industries.

* Author for correspondence:

${ }^{\dagger} . \mathrm{PhD}$ in Production Engineering in Quality Systems Area by Rio Grande do Sul University

Institution: Professor and researcher at Caxias do Sul University - Caxias do

Sul - RS - Brazil

E-mail: gsmilan@ucs.br

\footnotetext{
${ }^{\Omega}$ Master in Business Administration by Caxias do Sul University

Institution: Professor and researcher at Caxias do Sul University - Caxias do Sul - RS Brazil

E-mail: mbcsilva@ucs.br
}

$¥$ Graduated in Architecture and
Masters Student in Administration
at Caxias do Sul University
Institution: Masters Student in
Administration at Caxias do Sul
University - Caxias do SulRS -
Brazil
E-mail: bebber.suelen@gmail.com 


\section{INTRODUCTION}

he city of Flores da Cunha, located in the northeastern state of Rio Grande do Sul (RS), has an estimated population of 27,126 inhabitants, according to the 2010 census by IBGE - Instituto Brasileiro de Geografia e Estatística (Brazilian Institute of Geography and Statistics), and half of its economy is a result of the wine, beverage and furniture sectors. As an important source of employment and income, the furniture industry is a major source of growth, behind only the wine industries, which in quantity are the majority. Together, these industries employ hundreds of workers, which should be treated as valued internal customers by their employers (PINDER, 2003; FITZSIMMONS; FITZSIMMONS, 2010; ZEITHAML; BITNER; GREMLER, 2011).

In this context, the employees of these companies are the end users of the built environment, i.e., the physical infrastructure of companies or workspace that they offer to work productively, as it indeed have a direct impact on workers satisfaction, in their productivity and level of business competitiveness (HESKETT et al., 1994; Van der VOORDT, 2004; LEE, 2006).

It is noteworthy that, according to Ornstein, Bruna and Romério (1995) and Van der Voordt (2004), there is a strong relationship between the built environment and the behavior of employees (users of these resources and internal customers of organizations), and the first aspect affects the second and vice versa. Therefore, the central research question that this paper seeks to answer is: What are the attributes and dimensions of the built environment quality that are relevant in the performance of daily tasks of employees of five companies in the furniture sector of the city of Flores da Cunha (RS)?

As a result, the overall objective of the study was to identify the attributes and dimensions of the quality of the built environment that are relevant in the performance of daily tasks of employees related to their satisfaction for enterprises. For that, based on the evaluation of the expectations and perceptions of employees of the participating companies in their built environment, a scale was adapted in order to capture people's views regarding the quality and usefulness (PINDER, 2003; PINDER; WILKINSON, 1997) of their (built) work environment.

In addition, the following specific objectives were established: (i) raise the quality attributes inherent to the built environment; (ii) identify the dimensions of the intrinsic 
quality to the built environment, with its attributes; and (iii) assess the level of overall employee satisfaction (considering them as internal customers) of companies in relation to the built environment available.

Therefore, the model of evaluation of the built environment proposed by Pinder (2003) was used for serving routing to scale adaptation process and preparation of the research questionnaire, mainly to have potential application to inform and support to managers and other professionals involved (senior management, middle managers, architects and/or designers), providing robust information on the built environment available, which can affect productivity and business competitiveness.

\section{THEORETICAL FRAMEWORK}

According to Pinder (2003), there is a consensus that a workplace accommodates the information and knowledge, processing activities and tasks of an organization, including archiving, planning, creation, monitoring, analysis, decision and communication. In accordance, Lee (2006) points out that the working environment is related to the built environment (physical space), which is understood as a determining element for companies to have more satisfied employees and produce more and better. Therefore, employee satisfaction, that are, users of available built environment, is recognized as a business success factor and thus can be considered as a performance indicator. The employee satisfaction with the built environment is directly related to their satisfaction with their work and the company as well as organizational commitment, increasing productivity, reducing turnover rates and increasing the quality of products and/or the service provided to customers (LEE 2006; HESKETT et al., 1994; Van der VOORDT, 2004).

To improve and enhance the quality of built environments, it is appropriate to use feedback mechanisms from its users: post-occupancy evaluation (POE), which measures the satisfaction and the importance of the designed and built environment in relation to the most relevant attributes (ORNSTEIN; ROMÉRIO, 1992; ORNSTEIN; BRUNA; ROMÉRIO, 1995;. McDOUGALL et al, 2002 ; PREISER, 2002; O'NEILL; DUVALL, 2004; PREISER; VISCHER, 2005; CARTHEY, 2006; HADJRI; CROZIER, 2009, among others).

According to Preiser (2002), POE is the systematic process of evaluation environments performance after some time that they have been built and occupied. The POE focuses on the requirements of the occupants of physical environments (known as "buildings"), including relating to health aspects, safety, functionality, efficiency, comfort, aesthetics quality and user satisfaction. In a complementary way, McDougall et al. (2002) comment that the POE is the 
access to certain environmental performance, in everyday usage, for the purpose of providing information about the actual capacity of this particular environment. As the main focus in terms of workspace, the POE has to evaluate adequate space for human needs, in this case, in particular, the business community (O'NEILL; DUVALL, 2004; WAY; BORDASS, 2005).

Performance evaluation of a built basically can occur in two ways. At first, through technical evaluation, covering laboratory tests or in loco. Second, based on a behavioral assessment, from the point of view and judgment of its members (ORNSTEIN; ROMÉRIO, 1992). With that said, this work focused on behavioral assessment, from the point of view and judgment of the users of built environments evaluated, using the POE to serve as reference for future similar projects and how to control the overall quality of the built environment.

Of course, the quality of a building is related to a broader view of performance, is the ability of a particular "product" or characteristic or physical aspect (features) to satisfy its users now and in the future, which should be controlled (ORNSTEIN; ROMÉRIO, 1992; ORNSTEIN; BRUNA; ROMÉRIO, 1995). In the process of evaluating the performance of built environment, the POE is only one of the six stages of reviewing the building life (PREISER, 2002), which is illustrated in Figure 1.

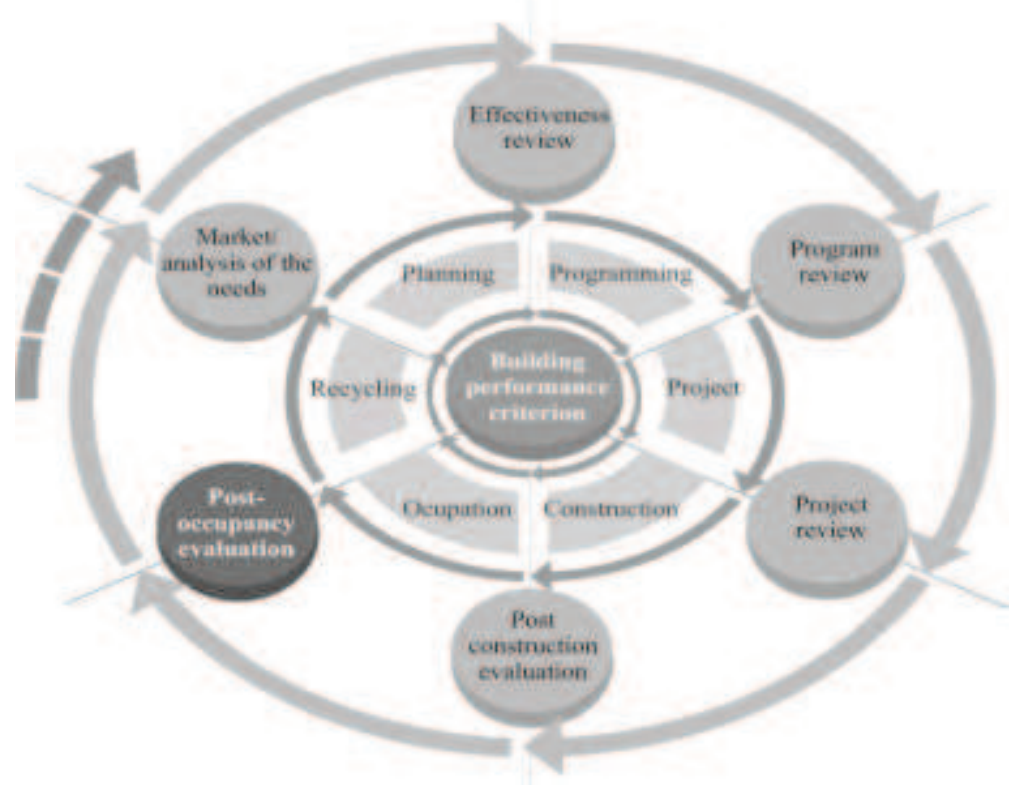

Figure 1 - Post Occupancy Evaluation Model

Source: Adapted From Preiser (2002). 
From the model of the POE process, should be given the priority to the needs of the occupants to ensure that their work environments allow develop the level of usefulness required to perform the service for which it is intended. According to Pinder (2003) and Price et al. (2004), the concept of usefulness regards the potential ability of a built environment to enable a service to occur or be performed properly. Therefore, the concept of usefulness of a built environment is related to its occupation and use. Its effectiveness should be judged according to the needs or expectations of its occupants, the company employees (PINDER; WILKINSON, 1997).

Therefore, Pinder (2003), Price et al. (2004) and Lee (2006) compare, similarly, the measurement of the value of an environment just as we measure the quality of a service, based on the judgment of users, related to their satisfaction with their work space. These same authors even suggest to use as a reference the structure of the SERVQUAL scale (PARASURAMAN; ZEITHAML; BERRY, 1985; 1988; 1991), one of the most used tools and with proven effectiveness in measuring services as a tool to measure a usefulness environment. This model is structured on the basis of the difference between the previous expectations for a particular service and the perceptions of service. The difference or gaps resulting from this comparative would result in the perceived quality.

Note that, Juran and Godfrei (1999) define quality as improving compliance of (technical) specifications with the fitness for use, providing the satisfaction of individuals from the conformity between the expected and actual performance. In addition, Grönroos $(1984 ; 1998 ; 2009)$ presents two types of dimensions that incorporate quality services. The technical quality (what is delivered, that is, the technical result) and the functional quality (how is such a result delivered). Thus, the overall assessment about the perceived quality would rest in judgment between what is expected (expectations) and what is experienced (perceptions or perceived performance).

In a building, according to Pinder (2003), its usefulness is also due to the expectations and perceptions of its occupants/users about what is available to/experienced by them. Moreover, the usefulness is considered a function of the attributes of a building, referred to as intrinsic aspects of quality (PINDER; WILKINSON, 1997). Thus, users of a built environment form an opinion on the usefulness of their work environment based on: (i) expectations of how your work environment should be, since such users generally have different demands or priorities related to the built environment (PINDER, 2003; PRICE et al., 
2004); and (ii) perceptions of how the work environment, in fact, consists, as these perceptions relate to all aspects of the work environment and are affected by the characteristics of users, including knowledge and previous experience, length of time in the environment work, personal tastes and social context in which they are inserted (PINDER, 2003; PRICE et al., 2004; NICOL; ROAF, 2005; CARTHEY, 2006).

But the divergence or discrepancy between the real usefulness (perceived) and the required usefulness (expected) presents two problems. The first, identify, and second, to quantify the difference (PINDER 2003). From the point of view of users of built environment, satisfaction is related to the confirmation or disconfirmation of their expectations (CHURCHILL Jr.; SURPRENANT, 1982; LEE, 2006; OLIVER, 1980; 2010), and the satisfaction increases as the performance/expectancy increases (OLIVER, 1980; 2010). If the perception reaches expectations, one is satisfied. If the experience is better than expected, then the perceived quality is high, and the person is overwhelmed. If the experience itself does not meet expectations, then the perceived quality is low, and the person will not be satisfied (JOHNSTON, 1994; 1995; OLIVER, 2010). Thus, the building will become obsolete or inadequate when users have their built environmental quality expectations exceeding their perceived levels of quality, i.e., when some attributes of the built environment does not meet the real needs of its occupants (PINDER; WILKINSON, 1997), which in theory can decrease their productivity in the workplace (Van der VOORDT, 2004).

Oliver (1980; 2010) and Johnston (1994, 1995) relate the model of (dis)confirmation of expectations to three possible outcomes related to (dis)satisfaction: (i) "dissatisfaction", resulting perceived poor quality (negative disconfirmation) which does not meet the expectations of users; (ii) "satisfaction" when the quality is adequate (expectations met); (iii) "enchantment", high quality, resulting in perceptions that exceed expectations (positive disconfirmation). The authors consider that user satisfaction/dissatisfaction is related to the involvement and sensitivity even with the usefulness/quality of what is evaluated, justifying that the greater the degree of user involvement on the usefulness/quality of the environment, the greater the sensitivity of the person and their judgments regarding their (dis)satisfaction with the received and experienced environment.

Moreover, Johnston (1994) defines a person's state of satisfaction with regard to an object as a tolerance zone. The tolerance zone is also used to evaluate the pre-performance expectations, which can vary: Minimum tolerable for optimal, with deserved, desirable and adequate performance. The significance of the tolerance zone is that the user, in this case, a 
built environment, could accept a variation in performance and no increase in the performance would only have effect on perceptions, that is, only when the performance moves beyond this limit would have a real effect on the perceived overall quality. The author suggests that the tolerance zone can be used as a kind of unifying construct between expectations, performance (perceptions), and results, as shown in Figure 2. Thus, adequate performance is set to be within the tolerance zone performance overall about the evaluated object.

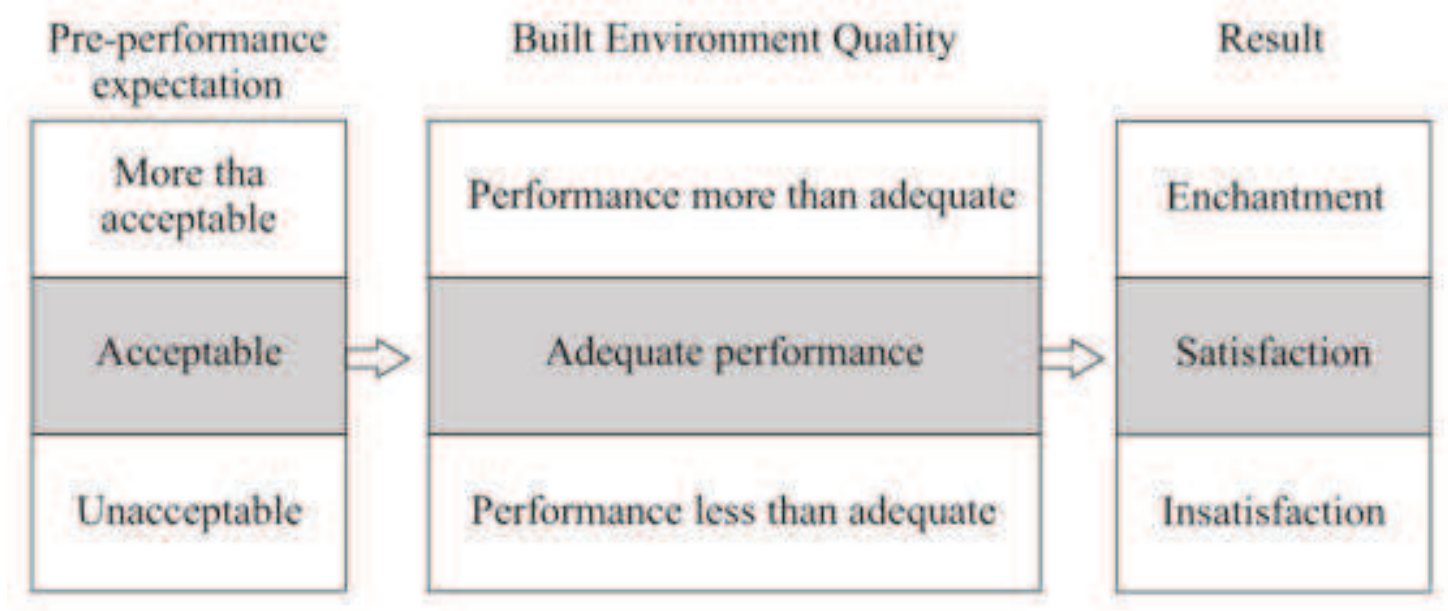

Figure 2 - Tolerance Zone

Source: Adapted From Johnston (1994).

Thus, when the utility of a built environment falls below the level required by the occupants, there is a risk that companies experience an increase in changes of work rates (staff turnover), reduced productivity, increased absenteeism (absence) of employees and even health care costs increase related to stress at work (PINDER, 2003; HUIZENGA et al., 2006; HADJRI; CROZIER, 2009). As a result, the present study explored the differences between expectations and perceptions of company employees on the aspects (attributes) quality inherent to the built environment, assessing the attributes and dimensions that best reflect the quality of the built environment under analyses.

\section{RESEARCH METHOD}

In this work, the research developed can be considered as quantitative character, operationalized through a survey, which is a research based on a structured questionnaire and directed to a representative sample of a population and intended to cause specific information from the perspective of respondents (MALHOTRA, 2006; FOWLER Jr., 2009; REMLER; VAN RYZIN, 2011).

The first step of this study was to identify the attributes and quality dimensions for the built environment to be evaluated. At this stage, were identified through literature review, 53 
attributes, divided into six dimensions of quality relevant to the built environment. The following dimensions were thus identified:

a) Appearance: examines how the effects of design, construction, use and operation affect the behavior of users (ORNSTEIN; BRUNA; ROMÉRIO, 1995; PINDER, 2003; PRICE et al, 2004);

b) Comfort: examines how the conditions for thermal, acoustic, light, ergonomic and ventilation comfort affect the behavior. Such aspects may act alone or together, causing the users sensations and positive and/or negative attitudes (ORNSTEIN; BRUNA; ROMÉRIO, 1995; PINDER, 2003; PRICE et al., 2004; NICOL; ROAF, 2005);

c) Configuration: evaluates existence and amount (dimension, size) of spaces available (PINDER, 2003; PRICE et al, 2004);

d) Functionality: assessing the functional performance of the spaces resulting from the architectural design (ORNSTEIN; ROMÉRIO, 1992; PINDER, 2003; PRICE et al, 2004; PREISER; VISCHER, 2005; CARTHEY, 2006);

e) Type of work: analyzes how the tasks individually affect users. The term task not only refers to the assignment of each one, but also all procedures with equipment necessary to perform it (ORNSTEIN; BRUNA; ROMÉRIO, 1995); and

f) Personal relationships: analyzes how the built environment in all its variables affects existing relationships, collaborating, or not, for the elevation of personal satisfaction and productivity (ORNSTEIN; ROMÉRIO, 1995; WAY; BORDASS, 2005).

For each dimension, the attributes were listed, which led to a structured questionnaire, using a concordance of a Likert scale of five points (MALHOTRA, 2006), ranging from "1. Strongly disagree" to " 5 . Strongly agree". In the data collection instrument, respondents were asked to indicate the degree of agreement with each statement related to quality attributes of the built environments under study (MALHOTRA, 2006; FOWLER Jr., 2009).

For an assessment of the representativeness of the content of the scales used in the measurement work that is proposed, Malhotra (2006) suggests that they should be evaluated according to their content. Content validity, also known as face validity, is to assess the comparability of variables and their conceptual definition aimed to evaluate the correlation between the individual items and concepts (HAIR Jr. et al, 2009; MALHOTRA, 2006). Therefore, the questionnaire was analyzed and evaluated by five experts in the building and quality area (quality researchers and/or professionals involved in the area of building). The suggestions were similar between them, for the proposed changes were related to the same 
issues. Some attributes were considered repeated and combined into a single question (variable), as was the case of: Cleaning appearance and cleanliness, acoustic comfort and noise caused by work itself, ergonomic comfort and minimum areas. Two other attributes, personal satisfaction and hierarchy were excluded because they are considered not relevant to the study, the built environment. Suggestions have also been incorporated on the language settings, to facilitate understanding of the respondents.

Of the 53 attributes initially identified in the literature, after the validation of content, it came up with a list of attributes which combined 55 questions relating to employee expectations the other 55 questions regarding their perceptions. To facilitate such understanding, follows Figure 3, which shows the six dimensions of quality contemplated and their attributes. In order to identify and eliminate potential problems in the questionnaire, Malhotra (2006) suggests the application of the pre-test questionnaire. For this purpose, a pretest was implemented, applied to 14 employees of one of the furniture industry which also received the final questionnaire. There was no problem about the questions (attributes or variables to be assessed). It only has been made small improvements in the language (text) and questionnaire layout. It is worth noting that the questionnaires carried out from the pretest were not incorporated into the final sample.

For data collection, the questionnaire was structured in three parts, containing: presentation of research, objectives and completing guidelines, issues relating to quality attributes inherent to the built environment (measured variables) and issues concerning the characterization of the profile of respondents. The presentation aims to direct the respondent on the questionnaire.

\begin{tabular}{|c|c|c|c|c|}
\hline \multirow{2}{*}{ 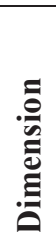 } & \multicolumn{2}{|c|}{ Questions } & \multirow[t]{2}{*}{ List of Attributes } & \multirow[b]{2}{*}{$\begin{array}{l}\frac{0}{\partial} \\
\frac{\pi}{\pi} \\
\frac{\pi}{\pi} \\
\nu\end{array}$} \\
\hline & 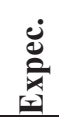 & $\begin{array}{l}\dot{0} \\
\stackrel{0}{0} \\
\stackrel{0}{0}\end{array}$ & & \\
\hline \multirow{11}{*}{ 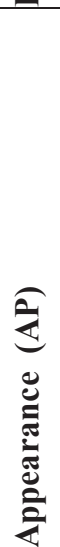 } & 1 & 56 & ... modern outsides. & AP1 \\
\hline & 2 & 57 & ... good external appearance. & AP2 \\
\hline & 3 & 58 & ... favorable internal format to proper functioning of their activities. & AP3 \\
\hline & 4 & 59 & ... good internal appearance. & AP4 \\
\hline & 5 & 60 & ... Good ceiling height (floor to ceiling height). & AP5 \\
\hline & 6 & 61 & ... built with suitable construction materials for use. & AP6 \\
\hline & 7 & 62 & ... nice color. & AP7 \\
\hline & 8 & 63 & ... good operational environment look. & AP8 \\
\hline & 9 & 64 & ... located within easy access to employees. & AP9 \\
\hline & 10 & 65 & ... located within easy access to customers. & AP10 \\
\hline & 11 & 66 & ... visually beautiful. & AP11 \\
\hline
\end{tabular}




\begin{tabular}{|c|c|c|c|c|}
\hline 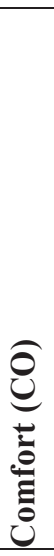 & $\begin{array}{l}15 \\
16 \\
17 \\
18 \\
19 \\
20 \\
21 \\
22\end{array}$ & $\begin{array}{l}67 \\
68 \\
69 \\
70 \\
71 \\
72 \\
73 \\
74 \\
75 \\
76 \\
77\end{array}$ & $\begin{array}{l}\ldots \text { pleasant temperature in summer. } \\
\ldots \text { pleasant temperature in winter. } \\
\ldots \text { possibility of temperature control. } \\
\ldots \text { good ventilation. } \\
\ldots \text { possibility of controlling the ventilation by opening or closing doors and windows. } \\
\ldots \text { Sun entery in the internal space. } \\
\ldots \text { enough brightness. } \\
\ldots \text { suitable height of fixtures. } \\
\ldots \text { most appropriate fixtures position to the applied working. } \\
\ldots \text { Provide appropriate space for the performance of daily. } \\
\ldots \text { Clean working environment. }\end{array}$ & $\begin{array}{l}\mathrm{CO} 1 \\
\mathrm{CO} 2 \\
\mathrm{CO} 3 \\
\mathrm{CO} 4 \\
\mathrm{CO} 5 \\
\mathrm{CO} 6 \\
\mathrm{CO} 7 \\
\mathrm{CO} 8 \\
\mathrm{CO} 9 \\
\mathrm{CO} 10 \\
\mathrm{CO} 11\end{array}$ \\
\hline (ְ) & $\begin{array}{l}23 \\
24 \\
25 \\
26 \\
27 \\
28 \\
29 \\
30 \\
31 \\
32 \\
33 \\
34 \\
35 \\
36\end{array}$ & $\begin{array}{l}78 \\
79 \\
80 \\
81 \\
82 \\
83 \\
84 \\
85 \\
86 \\
87 \\
88 \\
89 \\
90 \\
91\end{array}$ & $\begin{array}{l}\ldots \text { space for meetings. } \\
\ldots \text { enough quantity and size of space for meetings. } \\
\ldots \text { Space for teamwork . } \\
\ldots \text { layout (furniture, machinery) so that movement enables movement of people and } \\
\text { materials. } \\
\ldots \text { kitchen that meets all employees' needs. } \\
\ldots \text { clean and organized kitchen. } \\
\ldots \text { cafeteria. } \\
\ldots \text { clean and organized cafeteria. } \\
\ldots \text { Sufficient number of toilets. } \\
\ldots \text { Clean and organized toilets. } \\
\ldots \text { changing rooms with shower. } \\
\ldots \text { individual Locker in the locker room. } \\
\ldots \text { Parking for customers. } \\
\ldots \text { Parking for employees. }\end{array}$ & $\begin{array}{l}\text { CG6 } \\
\text { CG7 } \\
\text { CG8 } \\
\text { CG9 } \\
\text { CG10 } \\
\text { CG11 } \\
\text { CG12 } \\
\text { CG13 } \\
\text { CG14 }\end{array}$ \\
\hline 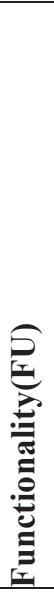 & $\begin{array}{l}37 \\
38 \\
39 \\
40 \\
41 \\
42 \\
43 \\
44 \\
45 \\
46 \\
47 \\
48\end{array}$ & $\begin{array}{l}92 \\
93 \\
94 \\
95 \\
96 \\
97 \\
98 \\
99 \\
100 \\
101 \\
102 \\
103\end{array}$ & $\begin{array}{l}\ldots \text { enough space for materials storage. } \\
\ldots \text { enough Internal space for movement of people and materials. } \\
\ldots \text { defined external paths for people. } \\
\ldots \text { defined external paths for vehicles. } \\
\ldots \text { suitable place for loading and unloading material. } \\
\ldots \text { recreational and rest areas for employees. } \\
\ldots \text { Adaptations or changes in workspaces. } \\
\ldots \text { Building extensions if necessary. } \\
\ldots \text { Appropriate signage indicating each work sector. } \\
\ldots \text { Suitable environment for disabled people. } \\
\ldots \text { Safe environment, to avoid the possibility of injury. } \\
\ldots \text { Distraction-free environment. }\end{array}$ & $\begin{array}{l}\text { FU1 } \\
\text { FU2 } \\
\text { FU3 } \\
\text { FU4 } \\
\text { FU5 } \\
\text { FU6 } \\
\text { FU7 } \\
\text { FU8 } \\
\text { FU9 } \\
\text { FU10 } \\
\text { FU11 } \\
\text { FU12 }\end{array}$ \\
\hline 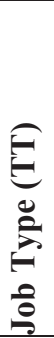 & 51 & $\begin{array}{l}104 \\
105 \\
106\end{array}$ & $\begin{array}{l}\text {... positioning of machinery or workplace favorable to productivity. } \\
\ldots \text { available PPE (personal protective equipment) against noise caused by the work } \\
\text { itself. } \\
\text {... Working islands so that the noisiest sectors do not generate discomfort and } \\
\text { inconvenience to others. }\end{array}$ & $\begin{array}{l}\text { TT1 } \\
\text { TT2 } \\
\text { TT3 }\end{array}$ \\
\hline
\end{tabular}




\begin{tabular}{|c|c|c|c|c|}
\hline 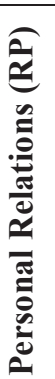 & $\begin{array}{l}52 \\
53 \\
54 \\
55\end{array}$ & $\begin{array}{l}107 \\
108 \\
109 \\
110\end{array}$ & $\begin{array}{l}\text {... interaction among employees. } \\
\ldots \text { communication between employees. } \\
\ldots \text { Communication with superiors. } \\
\text {... employees' autonomy in the performance of their duties. }\end{array}$ & $\begin{array}{l}\text { RP1 } \\
\text { RP2 } \\
\text { RP3 } \\
\text { RP4 }\end{array}$ \\
\hline
\end{tabular}

Figure 3 - Analyzed Dimensions And Quality Attributes

Source: Prepared By The Authors Based On The Literature On Constructive Environment And Structuring The Servqual Scale.

Regarding the data collection method the drop-off self-report method was used (HAIR Jr. et al., 2009), leaving the questionnaires in each of the five research participants furniture industries, under the manager's responsibility or responsible for Human Resources (HR), which distributed to the employees, collecting it back after completed and to then be delivered to researchers.

From the completion of the data collection process, they were checked and tabulated in order to be processed through Microsoft Excel software Office 2010 version and PASW® Statistics 18.0. At this stage, there was a consistent filling of the questionnaires, the incidence of missing responses or missing data (variables with more than $10 \%$ of non-responses were eliminated, while for presenting content below $10 \%$ of the mean answers were taken) (MALHOTRA, 2006; HAIR Jr. et al, 2009; ENDERS, 2010).

After the completion of the data processing, followed by the analysis and its interpretation. In order to check the dimensions of the intrinsic quality to the built environment, and its respective attributes, identified in the literature were converging with the present study, we used the Principal Component Analysis (also as factor loadings extraction method) to examine the set of interdependent relationships (MALHOTRA, 2006), explaining the existing covariance and correlations between variables (JOHNSON; WICHERN, 2007; HAIR Jr. et al, 2009; MULAIK, 2010), grouping them into factors (or dimensions). To obtain the factor that translate the attribute groups related to the constructs in question (MILAN; TREZ, 2005), the dimensions of the built environment quality, the standard eigenvalue equal to or greater than 1 was used (MALHOTRA, 2006; HAIR Jr. et al., 2009), without previously defining the number of factors.

To facilitate the interpretation of dimensions, the non-orthogonal method of oblique rotation of Oblimin factors was used (HAIR Jr. et al, 2009; MULAIK, 2010). In addition, there was the Bartlett sphericity test and the measures sampling adequacy of Kaiser-MeyerOlkin (KMO), measures to ensure that there are sufficient correlations in the statistical data to 
validate the application of factor analysis, which should be calculated to verify that the data is suitable for use of this technique. The Bartlett sphericity test evaluates if each variable correlates perfectly with itself, but no correlation with other variables (MALHOTRA, 2006). $\mathrm{KMO}$ is an index that compares the value of the correlations observed with the values of the partial correlations. KMO values less than 0.5 indicate that the correlations between pairs of variables cannot be explained by other variables and that factor analysis is not indicated (MALHOTRA, 2006; JOHNSON; WICHERN, 2007; MULAIK, 2010).

It was also analyzed the reliability of the scales, as of the Cronbach's alpha (MALHOTRA, 2006; HAIR Jr. et al., 2009; REMLER; VAN RYZIN, 2011). Cronbach's Alpha aims to verify the internal consistency of the data. This test has application in cases where the researcher needs to obtain a proper estimate of the magnitude of the measurement error. It is acceptable a value less than 0.70 (CHURCHILL Jr., 1979; MALHOTRA, 2006).

Finally, the overall employee satisfaction with the built environment provided by the companies was verified. Thus, in the end of the questionnaire, respondents attributed, in a Likert scale of five points, a level between "1. totally dissatisfied "to" 5. totally satisfied ", expressing their feelings about their overall satisfaction with the built environment.

\section{RESULTS AND DISCUSSION}

\subsection{RESEARCH PARTICIPANTS}

As shown in Table 1, 538 questionnaires were distributed in the five participating companies researched, resulting in a return of 350 valid cases. After the initial analysis of the data, the final sample included 318 valid cases, with a return of $59.10 \%$ on potential respondents (distributed questionnaires).

Table 1 - Research Participants (Respondents For Company)

\begin{tabular}{cccccc}
\hline Company & $\begin{array}{c}\text { Questionnaries } \\
\text { Distributed }\end{array}$ & Respondents & \% Return & Valid Cases & \% Return \\
\hline A & 51 & 39 & 76.47 & 39 & 76.47 \\
B & 42 & 32 & 76.19 & 29 & 69.05 \\
C & 220 & 107 & 48.63 & 98 & 44.55 \\
D & 180 & 140 & 77.77 & 128 & 71.11 \\
E & 45 & 32 & 71.11 & 24 & 53.33 \\
\hline Grand Total & $\mathbf{5 3 8}$ & $\mathbf{3 5 0}$ & $\mathbf{6 5 . 0 5}$ & $\mathbf{3 1 8}$ & $\mathbf{5 9 . 1 0}$ \\
\hline
\end{tabular}

Source: Data from the survey. 
With regard to sex (gender) of respondents, 146 (46\%) are male and 172 female (54\%). Predominantly, they are married people (125 respondents or $39 \%$ of the sample). In relation to their level of education, 85 respondents $(27 \%)$ have incomplete primary education. On past experience in the industry, 129 respondents (41\%) said they had never worked on another furniture industry.

\subsection{IDENTIFICATION OF QUALITY DIMENSIONS AND ATTRIBUTES OF BUILT ENVIRONMENT}

In order to identify the dimensions of the intrinsic quality of the built environment, with its respective attributes, the AFE was proceeded, which indicated a better explanatory power reflecting in seven, rather than six, dimensions of built environment quality of the evaluated furniture industries, as suggested by the literature. In order to debug the scales, the attributes with factor loadings below 0.5 were removed (HAIR Jr. et al., 2009; JOHNSON; WICKERN, 2007). In the final extraction of factors (dimensions), thus, emerged seven dimensions, explained by a total variance of $70.14 \%$. The results are shown in Table 2 , which shows that both the factor loadings, the value of the commonalities are greater than 0.5 , grouping in each identified dimension (or factors), their respective attributes.

Table 2 - Results for the Extraction Factors (Dimensions)

\begin{tabular}{c|c|c|c|c|c|c|c|c}
\hline \multirow{2}{*}{ Attributes } & \multicolumn{7}{|c|}{ Factors (or Identified Dimensions) } & \multirow{2}{*}{ Commonalities } \\
\cline { 2 - 8 } & $\mathbf{1}$ & $\mathbf{2}$ & $\mathbf{3}$ & $\mathbf{4}$ & $\mathbf{5}$ & $\mathbf{6}$ & $\mathbf{7}$ & \\
\hline $\mathbf{A P 1}$ & & 0.777 & & & & & & 0.677 \\
\hline $\mathbf{A P 3}$ & & 0,847 & & & & & & 0.706 \\
\hline $\mathbf{A P 4}$ & & 0.604 & & & & & & 0.639 \\
\hline $\mathbf{A P 5}$ & & 0.713 & & & & & & 0.677 \\
\hline $\mathbf{A P 7}$ & & 0.696 & & & & & & 0.609 \\
\hline $\mathbf{A P 8}$ & & 0.731 & & & & & & 0.543 \\
\hline $\mathbf{A P 9}$ & & & & & & 0.780 & & 0.624 \\
\hline $\mathbf{A P 1 0}$ & & & & & & 0.805 & & 0.764 \\
\hline $\mathbf{A P 1 1}$ & & 0.608 & & & & & & 0.575 \\
\hline $\mathbf{C O 1}$ & & & & & & & 0.753 & 0.779 \\
\hline $\mathbf{C O 2}$ & & & & & & & 0.676 & 0.782 \\
\hline $\mathbf{C O 3}$ & & & & & & & 0.692 & 0.723 \\
\hline $\mathbf{C O 4}$ & & & & & & & 0.726 & 0.723 \\
\hline $\mathbf{C O 5}$ & & & & & & & 0.655 & 0.617 \\
\hline
\end{tabular}




\begin{tabular}{|c|c|c|c|c|c|c|c|c|}
\hline $\mathrm{CO} 7$ & & & 0.738 & & & & & 0.666 \\
\hline $\mathrm{CO8}$ & & & 0.821 & & & & & 0.728 \\
\hline CO9 & & & 0.779 & & & & & 0.741 \\
\hline CG1 & & & & 0.987 & & & & 0.935 \\
\hline CG5 & 0.824 & & & & & & & 0.743 \\
\hline CG6 & 0.791 & & & & & & & 0.669 \\
\hline CG7 & 0.887 & & & & & & & 0.778 \\
\hline CG8 & 0.752 & & & & & & & 0.723 \\
\hline CG11 & 0.634 & & & & & & & 0.611 \\
\hline FU1 & & & 0.531 & & & & & 0.611 \\
\hline FU4 & & & & 0.976 & & & & 0.936 \\
\hline FU5 & & & 0.548 & & & & & 0.557 \\
\hline FU6 & 0.579 & & & & & & & 0.635 \\
\hline RP1 & & & & & 0.732 & & & 0.684 \\
\hline RP2 & & & & & 0.888 & & & 0.798 \\
\hline RP4 & & & & & 0.818 & & & 0.719 \\
\hline Eigenvalue & 11.555 & 2,443 & 1,934 & 1,665 & 1,497 & 1,391 & 1,259 & $\begin{array}{c}\% \text { Of } \\
\text { Accumulated } \\
\text { Variance }\end{array}$ \\
\hline $\begin{array}{c}\% \text { of Explained } \\
\text { Variance }\end{array}$ & 37.275 & 7,881 & 6,238 & 5,372 & 4,828 & 4,486 & 4,061 & 70.14 \\
\hline
\end{tabular}

Source: Result from the data analysis.

Note: Bartlett sphericity test: chi-square: 6268.127; KMO: 0.910; GL: 465,000; sig .: 0.000 .

Of the six dimensions initially identified in the literature (appearance, comfort, configuration, functionality, type of work and personal relationships), data analysis resulted in seven factors (or dimensions of quality), eliminating one of the previously identified dimensions (type of work) and also adding two new dimensions, which have been termed "business location" and "specific activities".

The elimination of the dimension "type of work" can be attributed to the fact that, based on the analyzed results, the survey participants did not identify such dimension, and its attributes, as an intrinsic dimension of the built environment. Similarly, the attributes that gave rise to two new dimensions ("business location" and "specific activity"), were retained in these dimensions, different from what is in the literature, preserving the understanding of the respondents (on data analysis ).

And such a change regarding the dimensions (and their attributes) in the literature may be due to the specific features every built environment, the type of work, from work activities 
or tasks, and especially the perception of individuals, which are influenced by their experiences with the built environment in question, their level of information and requirements and even cultural aspects.

It is important to mention that, sparingly, the 55 attributes initially evaluated, 31 of them were kept. In order to facilitate the understanding of these research findings, Table 3 lists both the dimensions of the quality of the built environment identified as their respective attributes.

Table 3 - Built Environment Quality Dimensions Identified and its Respective Attributes

\begin{tabular}{|c|c|}
\hline Quality Dimensions & Related attributes to Each Identified Quality Dimension \\
\hline Configuration & $\begin{array}{l}\text { CG5 - kitchen that meets all employees' needs. } \\
\text { CG6 - clean and organized kitchen. } \\
\text { CG7 - cafeteria. } \\
\text { CG8 - clean and organized cafeteria. } \\
\text { CG11 - changing rooms with shower. } \\
\text { FU6 - recreational and rest areas for employees. }\end{array}$ \\
\hline Appearance & $\begin{array}{l}\text { AP1 - modern outsides. } \\
\text { AP2 - good external appearance. } \\
\text { AP3 - favorable internal format to proper functioning of their activities. } \\
\text { AP4 - good internal appearance. } \\
\text { AP5 - Good ceiling height (floor to ceiling height). } \\
\text { AP7 - nice color. } \\
\text { AP8 - good operational environment look. } \\
\text { AP11- visually beautiful. }\end{array}$ \\
\hline Functionality & $\begin{array}{l}\text { CO7 - enough brightness. } \\
\text { CO8 - suitable height of fixtures. } \\
\text { CO9 - most appropriate fixtures position to the applied working. } \\
\text { FU1 - enough space for materials' storage. } \\
\text { FU5 - suitable place for loading and unloading material. }\end{array}$ \\
\hline Specific activities & $\begin{array}{l}\text { CG1 - space for meetings. } \\
\text { FU4 - defined external paths for vehicles. }\end{array}$ \\
\hline Personal relationships & $\begin{array}{l}\text { RP1 - interaction among employees. } \\
\text { RP2 - communication between employees. } \\
\text { RP4 - employees' autonomy in the performance of their duties. }\end{array}$ \\
\hline Company's location & $\begin{array}{l}\text { AP9 - located within easy access to employees. } \\
\text { AP10 - located within easy access to customers. }\end{array}$ \\
\hline Comfort & $\begin{array}{l}\text { CO1 - pleasant temperature in summer. } \\
\text { CO2 - pleasant temperature in winter. } \\
\text { CO3 - possibility of temperature control. } \\
\text { CO4 - good ventilation. } \\
\text { CO5 - possibility of controlling the ventilation by opening or closing doors and } \\
\text { windows. }\end{array}$ \\
\hline
\end{tabular}

Source: Result from the data analysis.

To analyze the internal consistency of the data for each of the seven dimensions identified, the results were analyzed from the Cronbach's alpha, which are shown in Table 4. Figures for the Cronbach's Alpha were considered satisfactory, as are values between 0.803 and 0.932 , above the minimum recommended in the literature. You can verify that the seven dimensions represent a total of 31 attributes, and there is a higher concentration of attributes in the Appearance Dimension (Factor 2), with eight attributes, then the Configuration 
Dimension (Factor 1) with six attributes and Functionality and Comfort Dimensions (Factors 3 and 7), each with five attributes.

Table 4 - Reliability of the Scales (Cronbach's Alpha)

\begin{tabular}{c|c|c|c}
\hline $\begin{array}{c}\text { Factors (or } \\
\text { dimensions) }\end{array}$ & Cronbach's alpha & Intrinsic attributes to Factor (Dimension) & $\begin{array}{c}\text { No Items of the } \\
\text { Scale }\end{array}$ \\
\hline $\mathbf{1}$ & 0.900 & CG5, CG6, CG7, CG8, CG11 and FU6 & 6 \\
$\mathbf{2}$ & 0.903 & AP1, AP2, AP3, AP4, AP5, AP7, AP8 and AP11 & 8 \\
$\mathbf{3}$ & 0.835 & CO7, CO8, CO9, FU1 and FU5 & 2 \\
$\mathbf{4}$ & 0.932 & CG1 and FU4 & 3 \\
$\mathbf{6}$ & 0.803 & AP9 and AP10 RP2 and RP4 & 2 \\
\hline
\end{tabular}

Source: Result from the data analysis.

\subsection{GENERAL SATISFACTION OF EMPLOYEES ABOUT THE BUILT ENVIRONMENT OF BUSINESS}

As for the overall satisfaction of the respondents in relation to the work environment (built environment) provided by the companies, , as shown in Table 5, a mean satisfaction of 3.64 was identified, which reflected in a general satisfaction score of $66,00 \%$. Although the vast majority of respondents (154 of them or 48.4\%) feel "partially satisfied", which is an interesting result, the overall score found, it can be inferred that the companies in the study still have several opportunities for improvement to be incorporated into their work environments.

Table 5 - General Satisfaction Regarding the Built Environment

\begin{tabular}{|c|c|c|c|c|}
\hline Degree of satisfaction & Frequency & $\%$ & Mean & $\begin{array}{c}\% \text { Overall } \\
\text { Average } \\
\text { Satisfaction }\end{array}$ \\
\hline 1. Totally dissatisfied & 05 & 1.6 & \multirow{6}{*}{3.64} & \multirow{6}{*}{$66.00^{1}$} \\
\hline 2. Partially dissatisfied & 32 & 10.1 & & \\
\hline $\begin{array}{l}\text { 3. Neither dissatisfied nor } \\
\text { satisfied }\end{array}$ & 82 & 25.8 & & \\
\hline 4. Partially satisfied & 154 & 48.4 & & \\
\hline 5. Totally satisfied & 45 & 14.1 & & \\
\hline Total & 318 & 100 & & \\
\hline
\end{tabular}

Source: Result from the data analysis

\footnotetext{
${ }^{1}$ The transformation of the mean $(3.64) \%$ on overall average satisfaction $(66 \%)$, was calculated by using the following formula: (mean - 1) x $(100 / 5-1)$ been " 5 " the number of alternative answers on the Likert scale used in the study.
} 


\section{FINAL CONSIDERATIONS}

The literature on the quality of the built environment indicates that employees who are more satisfied with the physical environment produce better (HESKETT et al., 1994; CARTHEY, 2006; LEE, 2006). In this context, understanding the perceived quality of resources and the available desktop and mainly employee satisfaction are important aspects in business success, configuring as a performance indicator. Therefore, it is from the judgment of the front staff to their expectations and their perceptions of the work environment that the overall quality is formed and, from this, managers must maximize the satisfaction of its employees in order to improve performance of their daily tasks and business performance (HESKETT et al., 1994; PRICE et al., 2004; LEE, 2006; Van der VOORDT, 2006).

Johnston and Michel (2008) speak of failure recovery in services as an alternative to resume the relationship with an unhappy customer to a state of satisfaction. Also the purpose of service recovery is to improve a company as internal services, within a logic of work processes and resources involved (FITZSIMMONS; FITZSIMMONS, 2010). Such improvements should lead to cost savings, with the removal of inefficient processes and also the smaller failures in the future and therefore fewer employees and customers or dissatisfied consumers. And that, of course, will bring some impact on profit and the profitability of companies (HESKETT et al., 1994; ZEITHAML; BITNER; GREMLER, 2011).

It is important to highlight that identifying which aspects (attributes and dimensions of quality) deserve greater attention in the built environment, aiming at a more accurate routing of investments (reforms, adjustments, aspects related to health and worker productivity) to be prioritized by companies (LEE, 2006; TURPIN-BROOKS; VICCARS, 2006); as well as the specification of employee needs, understanding their expectations and perceptions of the built environment and their work routines, helping to avoid an incomplete, inappropriate or unproductive environment (LEE, 2006; WAY; BORDASS, 2005). That is, such an understanding can increase satisfaction with regard to the built environment, the productivity of work teams and, as a result, the competitiveness of companies.

Therefore, this research has the following reflections: (i) the information collected (perceptions) can have a positive impact on firms' strategic planning, validating the efforts of managers to understand how daily decisions affect the future performance (productivity, cost, profit and profitability) of the business (O'NEILL; DUVALL, 2004; Van der VOORDT, 2004; HESKETT et al, 1994); (ii) adapt a quality scale of the built environment, in the SERVQUAL case, it may be helpful for a better understanding of its usefulness (PINDER 
2003); (iii) that research like this can be an effective mechanism for feedback to managers and employees of the companies, helping to improve the quality of the built environment in a particular type of work (in the case of furniture industries) (PREISER, 2002; PREISER; VISCHER, 2005), and greatly impact on user satisfaction (Van der VOORDT, 2004; CARTHEY, 2006; HADJRI; CROZIER, 2009;. HUIZENGA et al, 2006); (iv) the importance of generating robust and reliable information for investors, managers, designers and owners of furniture industries, assisting in the planning and execution of projects to avoid repeating mistakes (PREISER, 2002); and (v) the understanding that monitoring the quality of a building (built environment / workspace) and the notification of managers when the perceived performance does not reach an acceptable standard may have a negative effect on the productivity of companies (PREISER, 2002; HADJRI; CROZIER, 2009) is something essential to the implementation of corrective measures.

Whereas the researched object does not have a lot of work in the environmental quality area of the built environment in Brazil, this research sought to initially develop and adapt a measuring scale and assessment of the expected and perceived quality of the built environment based on the opinion of employees of industries in the furniture sector. As a possibility for future research, it is pertinent for further investigation to seek to ratify or identify the attributes related to the dimensions of the quality of the built environment under study. If the dimensions resulting from this research are considered, it is possible that in different environments different behaviors occur, resulting in the employee satisfaction, which would allow a comparison between different work environments, for example, as in the case of hospitals (CARTHEY, 2006).

To complement this research, it is suggested to carry out studies with replication of the scales, to allow making comparisons between the results obtained over time. As an important tool to manage expectations and perceptions of users, it can be suggested to perform researches seeking to identify companies with employees of the minimum levels, appropriate and desired quality in order to establish a "zone of tolerance" to understand and meet environmental usefulness built the furniture industry or other activity of companies (JOHNSTON, 1994; 1995).

Finally, it is also suggested the possibility to direct studies in which the consequences of employee satisfaction of companies are evaluated, regarding the workspace, relating them to aspects such as their retention and loyalty (HESKETT et al ., 1994; JOHNSTON, 1995; ZEITHAML; BITNER; GREMLER, 2011). Such studies could drive the adoption of strategic 
actions by companies in order to lead them to the retention and loyalty of employees and increasing the productivity, profits and profitability (HESKETT et al., 1994; O'NEILL; DUVALL, 2004; PRICE et al., 2004; LEE, 2006; WAY; BORDASS, 2005), making them more competitive.

\section{REFERENCES}

CARTHEY, J. Post occupancy evaluation: development of a standardized methodology for Australian health projects. The International Journal of Construction Management, v. 6, n. 1, p. 57-74, 2006.

CHURCHILL Jr.; G. A. A paradigm for developing better measures of marketing constructs. Journal of Marketing Research, v. 16, n. 1, p. 64-73, 1979.

; SUPRENANT, C. An investigation into the determinants of customer satisfaction. Journal of Marketing Research, v. 19, n. 4, p. 491-504, 1982.

ENDERS, C. K. Applied missing data analysis. New York: The Gilford Press, 2010.

FITZSIMMONS, J. A.; FITZSIMMONS, M. J. Administração de serviços: operações, estratégia e tecnologia da informação. 6. ed. Porto Alegre: Bookman, 2010.

FOWLER Jr., F. J. Survey research methods. $4^{\text {th }}$ edition. Thousand Oaks: Sage Publications, 2009.

GRÖNROOS, C. A service quality model and its marketing implications. European Journal of Marketing, v. 18, n. 4, p. 36-45, 1984.

. Marketing services: the case of a missing product. Journal of Business \& Industrial Marketing, v. 13, n. 4/5, p. 322-338, 1998.

Marketing: gerenciamento e serviços. 3. ed. Rio de Janeiro: Elsevier, 2009.

HADJRI, K.; CROZIER, C. Post-occupancy evaluation: purpose, benefits and barriers.

Facilities, v. 27, n. 1, p. 21-33, 2009.

HAIR Jr., J. F. ; BLACK, W. C.; BABIN B. J.; ANDERSON, R. E.; TATHAM, R. L.

Análise multivariada de dados. 6. ed. Porto Alegre: Bookman, 2009.

HESKETT, J. L.; JONES, T. O.; LOVEMAN, G. W.; SASSER Jr., W. E.; SCHLESINGER, L. A. Putting the service-profit chain to work. Harvard Business Review - Business

Classics: Fifteen Key Concepts for Managerial Success, p. 110-120, 1994.

HUIZENGA, C.; ABBASZADEH, S.; ZAGREUS, L.; LEHRER, D. Measuring indoor environmental quality: a web-based occupant satisfaction survey. 2006. Available in: http://www.cbe.berkeley.edu/research/briefs-survey.htm.

JOHNSON, R. A.; WICKERN, D. W. Applied multivariate statistical analysis. $6^{\text {th }}$ edition. Upper Saddle River: Pearson / Prentice Hall, 2007. 
JOHNSTON, R. The zone of tolerance exploring the relationship between service transitions and satisfaction with overall service. International Journal of Service Industry Management, v. 6, n. 2, p. 46-61, 1994.

The determinants of service quality: satisfiers and dissatisfiers. International Journal of Service Industry Management, v. 6, n. 5, p. 53-71, 1995.

; MICHEL, S. Three outcomes of service recovery. International Journal of Service Industry Management, v. 28, n. 1, p. 79-99, 2008.

JURAN, J. M.; GODFREI, A. B. Juran's quality handbook. $5^{\text {th }}$ edition. New York: McGraw-Hill, 1999.

LARENTIS, F. Comportamento do consumidor e marketing de relacionamento. Curitiba: IESDE, 2009.

LEE, Y. S. Expectations of employees toward the workplace and environmental satisfaction. Facilities, v. 24, n.. 9/10, p. 343-353, 2006.

MALHOTRA, N. K. Marketing research: an applied orientation. $5^{\text {th }}$ edition. New Jersey: Prentice Hall, 2006.

McDOUGALL, G.; KELLY J. R.; HINKS J; BITITCI, U. S. A review of the leading performance measurement tools for assessing buildings. Journal of Facilities Management, v. 1, n. 2, p. 142-153, 2002.

MILAN, G. S.; TREZ, G. Pesquisa de satisfação: um modelo para planos de saúde. RAEeletrônica, v. 4, n. 2, art. 17, 2005.

MULAIK, S. A. Foundations of factor analysis. $2^{\text {nd }}$ edition. Boca Raton: Taylor \& Francis Group, 2010.

NICOL, F.; ROAF, S. Post-occupancy evaluation and field studies of thermal comfort. Building Research and Information, v. 33, n. 4, p. 338-346, 2005.

OLIVER, Richard L. A cognitive model of the antecedents and consequences of satisfaction decisions. Journal of Marketing Research, v. 17, n. 4, p. 460-469, 1980.

E. Sharpe, 2010.

Satisfaction: a behavioral perspective on the consumer. $2^{\text {nd }}$ edition. New York: M.

O’NEILL, M.; DUVALL C. A six sigma quality approach to workplace evaluation. Journal of Facilities Management, v. 3, n. 3, p. 240-253, 2004.

ORNSTEIN, S.; BRUNA, G.; ROMÉRO M. Ambiente construído e comportamento: a avaliação pós-ocupação e a qualidade ambiental. São Paulo: Studio Nobel, 1995.

ORNSTEIN, S.; ROMÉRO M. Avaliação pós-ocupação do ambiente construído. São Paulo: Studio Nobel, 1992. 
PARASURAMAN, A.; ZEITHAML, V. A.; BERRY, L. L. A conceptual model of service quality and its implications for future research. Journal of Marketing, v. 49, n. 4, p. 41-50, 1985.

;____ SERVQUAL: a multi item scale for measuring consumer

perception of service quality. Journal of Retailing, v. 64, n. 1, p. 12-40, 1988.

;___ Refinement and reassessment of the SERVQUAL scale. Journal of

Retailing, v. 67, n. 4, p. 420-450, 1991.

PINDER, J. A method for evaluating workplace utility. Property Management, v. 21, n. 4, p. 218-229, 2003.

; WILKINSON, J. S. A behavioral approach to the obsolescence of office property. Sheffield Hallam University - School of Environment and Development: Sheffield, 1997.

PREISER, W. F. E. Continuous quality improvement through post-occupancy evaluation feedback. Journal of Corporate Real State, v. 5, n. 1, p. 42-57, 2002.

2005.

; VISCHER, J. Assessing building performance. Butterworth Heinemann: Elsevier,

PRICE, I.; PINDER, J.; HAYNES, B.; CLARK, L. The boundaries to workplace evaluation. Facilities Management Graduate Centre, 2004.

REMLER, D. K.; VAN RYZIN, G. G. Research methods in practice: strategies for description and causation. Thousand Oaks: Sage Publications, 2011.

TURPIN-BROOKS, S.; VICCARS, G. The development of robust methods of post occupancy evaluation. Facilities, v. 24, n. 5/6, p. 177-196, 2006.

WAY, M.; BORDASS, B. Making feedback and post-occupancy evaluation routine 2: soft landings - involving design and building teams in improving performance. Building Research and Information, v. 33, n. 4, p. 353-360, 2005.

Van der VOORDT, T. J. M. Productivity and employee satisfaction in flexible workplaces. Journal of Corporate Real Estate, v. 6, n. 2, p. 133-148, 2004.

ZEITHAML, V. A.; BITNER, M. Jo; GREMLER, D. D. Marketing de serviços: a empresa com foco no cliente. 5. ed. Porto Alegre: Bookman, 2011. 